\author{
A.A. Badmaev \\ Institute of Archaeology and Ethnography, \\ Siberian Branch, Russian Academy of Sciences, \\ Pr. Akademika Lavrentieva 17, Novosibirsk, 630090, Russia \\ E-mail: badmaevaa@ngs.ru
}

\title{
Traditional Buryat Beliefs About Birds
}

This study, based on ethnographic, linguistic, and folk materials, describes and interprets Buryat ideas of birds. The analysis of lexical data reveals the principal groups of birds according to the Buryat folk classification. The bat's status is indistinct, since bats are not subordinate to the kings of the animal world. Diagnostic criteria underlying the classification of birds are outlined. The main criterion was whether a bird was beneficial or harmful. Ornithomorphic images in Buryat mythology, folklore, and ritual are described. Cult birds and bird totems are listed, and relics of local bird cults (those relating to swan, goose, duck, pigeon, and eagle) are revealed. Birds with positive connotations are the swan, crane, swallow, pigeon, eagle, and eagle-owl. Those with negative connotation are the kite, raven, crow, quail, cuckoo, and hoopoe). The attitude toward ducks, hawks, magpies, and jackdaws is ambivalent. Certain birds (ducks and ravens) were related to cosmogonic ideas; others (swan, goose, eagle, etc.) were endowed with a werewolf capability. The raven, the cuckoo, and the hoopoe symbolized natural cycles, whereas the magpie and the quail were associated with the soul. The role of bird images in the mytho-ritual practices is discussed. The Buryat mythological ideas reflected not only specific ethnic views of certain birds, but also universal ones.

Keywords: Buryats, worldview, shamanism, birds, folklore, ritual.

\section{Introduction}

Images of birds are embedded in various areas of the Buryat culture, including beliefs associated with space and time, diseases, totemic ancestors, various mythical characters, etc., as well as family and tribal rituals, such as life-cycle rituals. Pre-revolutionary and Soviet ethnographers (Khangalov, 1959, 1960; Potanin, 2005; Batorov, 1927; Galdanova, 1987) have touched upon this topic in their studies, but images of birds remain little studied in Buryat ethnography. The purpose of this study is to identify and describe traditional Buryat ornithomorphic beliefs.

This study is based on literary, museum, archival, and field evidence. The main sources are the folkloric data collected by M.N. Khangalov, G.N. Potanin, and
T.Z. Zhamtsarano. Linguistic information was taken from the Dictionary "Buryaad-orod toli" (2010), which contains names of birds, their organs and anatomy, etc. in the Buryat language. This study follows the structural and semiotic method.

\section{Bird-related beliefs of the Buryats}

Over the past three centuries, in the Baikal region, 363 bird species have been recorded (Baikal..., 2009: 147). Not all of them were given names in the Buryat language; the named birds obviously played a sacred or hunting role among the Buryats.

Buryats distinguished birds in the animal kingdom by type of birth, which was called yahan turel 'bone

\footnotetext{
Archaeology, Ethnology \& Anthropology of Eurasia 48/2 (2020) 106-113 E-mail: Eurasia@archaeology.nsc.ru (C) 2020 Siberian Branch of the Russian Academy of Sciences

(C) 2020 Institute of Archaeology and Ethnography of the Siberian Branch of the Russian Academy of Sciences
} 
birth' (Khangalov, 1959: 219) among the Shamanists, and yndegenhoo turekhe 'birth through the egg' among the Buddhists.

Buryat vocabulary contains words and phrases conveying morphological features of birds, such as shubuunai khonshoor 'beak', ude(n) 'feather', urbeelge 'tail feather', zheber 'flight feathers', hodo(n) 'flight wings', ude dali, dali, zheguur 'wings', ere maryaan uden 'mottled plumage', uderkheg huul 'feathery tail' (Buryaad-orod toli..., 2010: Vol. I, p. 255, 361, 362; vol. II, p. 326, 444, 557, 621). These features are reflected in the names of the classes of birds: dali zheguurte shubuun 'winged birds', zheguurten 'feathered beings'. It is curious that in accordance with such feature as presence of tail, the Buryats united birds and animals in a single community of huulten 'tailed beings'. In the class of birds, the Buryats distinguished such groups as, for example, myakhasha shubuud 'birds of prey', lit. 'meat-loving birds', or nugaha zagahad 'waterfowl'.

Unlike a number of other ethnic groups, the Buryats have an unclear attitude toward the status of bats (the representatives of the Chiroptera order adapted for flight) in the popular classification of animals. The Buryats believed that bats are not subordinate to any kings of the animal world (Khangalov, 1960: Vol. 3, p. 23). This idea was reflected in the plot of some folklore sources; for example, in the following tale: "They elected eagle as king and started to subjugate all birds to him. The bat (urmushe) refused to obey, saying that although it had wings, it also had teeth. When the mice began to elect their king and chose Tsagan Amyn Khuluguna, the bat said that she was not a mouse, since she had wings. This is why the birds and mice sentenced her to fly only at night and not during the day" (Potanin, 2005: 174). According to this fragment, the Buryats, like the Slavic and Baltic-Finnish peoples, considered the bat to be a night bird (Gura, 1997: 603; Vinokurova, 2007: 18). The lexical evidence indicates that bats were perceived to be similar to butterflies: along with the name uremshoo 'bat', the name harhan erbeekhei 'playful butterfly' was used, although the latter definition is not entirely consistent with identifying the class of insects based on the morphology of "very small beings".

Birds were primarily associated with the sky. According to traditional beliefs of the Buryats, the sky is divided into western and eastern portions, which have opposite qualities depending on the celestial dwellers abiding therein. Some birds obeyed the will of the western (white) tengerinuud 'celestial dwellers', while other birds obeyed the eastern (black) ones. This division of birds was manifested in the color of their plumage, primarily in the predominance of contrasting colors-black and white. For example, the black plumage of the raven indicates that it belongs to black zayaan 'patron spirit'; conversely, the white color of the swan's feathers is associated with luminous powers. Of course, endowing birds with positive or negative connotations depended mainly on their perception as harmful or harmless and beneficial for the Buryats and their economy. We should mention that any birds that were the totems of individual ethnic communities were considered positive.

One criterion for the division of birds was their edibility. Buryats avoided eating bird meat of the Accipitridae, Falconidae, and Corvidae. The main hunted birds were waterfowl and fowl from pine forests.

Buryats believed that the birds had a king. In the above-mentioned tale, this king was the eagle, which indicates the universal nature of such a belief: the TurkicMongolian, Slavic, and other peoples considered the eagle to be a royal bird (Burnakov, 2010: 157; Gura, 1997: 610). The mythical hero Khan Kherdeg shubuun 'Khan Garudi bird', with its Hindu-Buddhist origins, was called the lord of the birds. Its appearance in mythology probably resulted from the Early Medieval contacts between ethnic groups in Southern Siberia, and the adoption of Tibetan Buddhism in some of these groups in the 17th-19th centuries.

Buryats paid attention to the melodiousness of sounds made by birds, and specified the category of duusha shubuud 'songbirds'. In addition, there was a circle of birds whose voices Buryats considered especially attractive; this is confirmed by the presence of the corresponding expressions in their language: shakhanaa(n) 'chirping (of magpie)', 'affectionately sounding (about cuckoo cuckooing)', oin duusha shubuukhai 'forest songbird', etc.

Buryat anthroponymy features appellatives homonymous with the names of birds: Byrkhuut 'eagle', Galuun 'goose', Nugahan 'duck', Kharsaga 'hawk', Kheree 'raven', Turlaag 'crow', Khukhei 'cuckoo' (Mitroshkina, 1987: 82-83). Like other "deceptive names", they were believed to protect the life of the child from encroachments of evil spirits.

\section{Birds in mythology, folklore, and rituals of the Buryats}

Among the waterfowl, Buryats gave an important position to the swan. Traces of its cult have been found in a number of ethnic communities, such as the Khori-Buryats, Khongodors, and others. The Khongodors considered the swan their totem animal, and so did not hunt them. Moreover, they performed a ritual sprinkling of flying swans with milk. However, some groups of Buryats permitted the killing of this bird for ritual purposes. People were obliged to give the hunter a horse for the killed swan; moreover, they tried to quickly exchange such prey from each other, and this happened many times until the carcass started to rot (T.S. (Savenkov Timofei), 1925: 16). The swan might have been associated with celestial grace, 
which the Buryats prized. According to Khangalov, the Buryats were afraid of swans, because they believed that these birds had a heavenly patron (1960: Vol. 3, p. 37). According to fairy-tales and legends, swans with red feet were the daughters of the sky (Potanin, 2005: 25), and could turn into earthly women. In Buryat fairy-tales, a graceful female gait was associated with the image of the swan: "the beautiful Khan's wife walks around like a swan bird, steps so smoothly and lightly that flowers and grass arise behind her" (Buryatskiye volshebniye skazki, 1993: 42-47).

Images of the swan appear on cult items of the Buryats. Notably, attributes of the Khori-Buryat shaman, like the khese tambourine, had metal pendants with representations of this bird (Galdanova, 1987: 41). A pair of copper figurines of flying swans (male and female) decorates the shaman's outfit among the Agin Buryats, which is kept in the Russian Museum of Ethnography (RME, No. 783-39). During the shaman's travels, swans were his assistant spirits.

People also associated shapeshifting with another member of the waterfowl-the goose (galuun, turog shubuun 'gray goose' (Anser anser)). For instance, it was widely believed that the Tarasin akhanuts (spirits of famous shamans) knew how to turn into geese during their lifetime (Khangalov, 1959: Vol. 2, p. 180). The Yanguts called the goose their mythical ancestor. These Buryats performed seasonal sacrificial rituals: in the spring they were dedicated to the arrival of geese, and in the fall to their departure (Manzhigeev, 1960: 79).

The image of another waterfowl (a duck) was associated with the cosmogonic idea. According to the myth, the angir 'turpan' (Melanitta fusca) dived into primordial ocean at the request of the demiurge SombolBurkhan, and brought a lump of black soil in its beak and red clay in its feet, from which the Creator created earth (Khangalov, 1960: Vol. 3, p. 7). A Buryat legend speaks about khun-nugahan a 'man-duck', a rational being: "a man-duck looks very much like a man... A womanduck looks like a woman: it is like she wears a hat on her head, two braids, a necklace, and a fur coat" (Ibid.: 378). This image was probably not accidental and might echo the ancient local cult of the duck. At the same time, the duck also carries a negative connotation in the traditional beliefs of the Buryats. The nesting of ducks in a summer house before the family would move there from the winter house was a bad sign (Potanin, 2005: 133). There was a widespread belief that the turpan eats its chicks (Khangalov, 1960: Vol. 3, p. 28-29). These examples testify to the ambivalence of the image of the duck in the Buryat culture.

The image of the crane does not surface very frequently in the worldview of the Buryats, but it is obvious that this bird was perceived in a positive way. The Buryats had bans on killing cranes and eating their meat. It was believed that khara tokhoryuun 'the black crane' (Grus monacha) had heavenly patrons (Ibid.: 71). In fairy-tales, the crane competes with the eagle in the struggle for the place of the king of birds, but the anger shown by the crane in relation to the quail, who opposed his candidacy, incurs disfavor from the assembly of birds (Podgorbunsky, 1915: 92). Mythological beliefs about the crane, which did not become a royal bird, are known among a number of Turkic peoples of Siberia (Potanin, 2005: 185).

There is no reason to claim that the crane was a totemic bird among the Buryats. It is true that one publication cites the appeal of the Alar Buryats to Ongon Boronkhi, mentioning the crane as a totem (Batorov, Khoroshikh, 1926: 56-57), but most likely there was a mistake in the text: the tsen-shubuun bird (supposedly, a Siberian white crane) was called the ancestor of the Khori-Buryats along with the swan, although it should have been the sen shubuun 'female swan' that was indicated.

Two species of swallows live in southeastern Siberiathe barn swallow (Hirundo rustica) and the sand martin (Riparia riparia). In the traditional beliefs of the Buryats, swallows belong to positive birds. The plot of the fairytale "The Swallow and the Gadfly" confirms this point: the swallow saves people from danger-after learning that a huge gadfly declared the human blood to be the most delicious, it flies to tell this to Erlen Nomon-Khan, the lord of the underworld (Buryatskiye narodniye skazki..., 2000: 91-93). Notably, this plot with slight variations has been found in the folklore of other Turkic-Mongolian peoples (for example, the Dörbet people: (Potanin, 2005: 183)).

It was considered a good sign if a swallow built a nest in a log cabin or barnyard (Field Materials of the Author (FMA)). The popular tradition forbade killing swallows or destroying their nests (Khangalov, 1960: Vol. 3, p. 72). The swallow was considered the carrier of divine grace, which was reflected in a sign: when a swallow arrives, there will always be kurunga in the family. The dairy product kurunga belongs to the "white" or sacred food and symbolizes khesheg 'happiness' of the family - it could not be given to other people, otherwise it was believed that the family well-being would go away. It was considered a bad omen if a swallow threw a chick out of its nest (Potanin, 2005: 133). Such bird behavior was regarded as a sign of imminent disaster threatening the family (FMA).

The image of the dove, which in the Southeastern Siberian outdoors appears in two species - the common pigeon (Columba livia) and the oriental turtle dove (Streptopelia orientalis) - appears to be unclear. Its celestial semantics is indicated by one of the names used for that bird-burkhanai shubuun 'god's bird'. It reflects the ancient religious views of the Cis-Baikal Buryats, and is not associated with the Christianization process. This was the name of a Lower Uda Buryat clan (Buryaty, 2004: 50). In addition, based on the evidence gathered 
by Khangalov (1960: Vol. 3, p. 377), bird Guli ekhe (lit. 'female dove, the mother') was believed to be the ancestor of the Ikinat clan of the Balagan Buryats. According to popular beliefs, the dove was the orphaned girl, who was mistreated by her brother's wife; God took pity on her and turned her into a bird tuutei shubuun 'turtledove' (Ibid.: 29).

Among the daytime birds of prey, the Buryats especially revered the eagle (ekhe shubuun, kharabsar, burged). In the Baikal region, there occur various species of the Accipitridae. Most of them have ornithonyms in the Buryat language: talyn burged, tad shubuun 'steppe eagle', dalayn burged 'sea eagle', tarbazha 'forest eagle', khabtar burged 'imperial eagle', tas shubuun 'bearded vulture', sagaan huultei burged 'white-tailed eagle'. The respectful attitude of the Buryats to the image of the eagle is conveyed by popular idioms: burged kharasa 'eagle look' and burged zorig 'eagle courage'. Admiration for large size, wingspan, height, and speed of flight of the eagle, as well as its fearlessness in battle was expressed in one of its names-ekhe shubuun 'great bird'. This name of the eagle is linked with its perception as a bird with extraordinary sacred power.

Analysis of the evidence collected by M.N. Khangalov (Ibid.: 30-31) and P.P. Batorov (1927: 79) has shown that the cult of the eagle (more precisely, the white-tailed eagle (Haliaeetus albicilla)) emerged among one portion of Buryats; and this predator was also revered by another group of Buryats. Olkhon Island was considered the place of origin of the eagle cult: according to a legend, the eagle was a man, the son of the mythical owner of Olkhon Shubuun-noion 'Bird-lord', but after eating carrion, he could no longer take on the human form; the Olkhon white-tailed eagles originated from him. As we can see, the Buryats associated the idea of shapeshifting with this bird. The transmogrification of the mythical hero Geser into a dark gray eagle is another example of shapeshifting.

The eagle was a totem; it was forbidden to kill it. It was believed that anyone who laid a hand on this bird was subject to cruel punishment by the lord-spirit of Olkhon, who according to the Buryats was one of the thirteen northern Noyans. He served as the chief judge in the noyohi suglaan 'assembly of the spirits of tribal leaders' (Shamanskiye poveriya..., 1890: 17), and was revered as the patron deity of marriage (Zhamtsarano, 2001: 93). According to the beliefs of the Upper Lena Buryats, Shubuun-noyon had three eagle sons: Khara ereen burged 'Black-and-mottled eagle', Shara ereen burged 'Yellowand-mottled eagle', and Gal shara burged 'Fiery yellow eagle'. Every year they were offered family sacrifices; the invited shaman "squawked, imitating eagles... prayed, asking for protection and patronage of the householder" (Ibid.: 328). It is curious that in addition to customary domestic animals, pine forest fowl (hazel grouse and black grouse) were sacrificed to all of the characters mentioned above (Ibid.: 336). According to a source from the 18 th century, the Buryats, if "an eagle... is flying over their yurt..., sacrifice milk, tea, or whatever is at hand at the moment to it, and they dance around, jump, and hop" (cited after (Zinner, 1968: 193)).

Khan Khoto baabai 'King Khoto the father', who had the ability to turn into an eagle, belonged to the thirteen northern Noyans (Natsov, 1995: 80). Notably, the word khoto is paralleled in the Yakut language: khotoi 'eagle' (Galdanova, 1987: 37).

According to G.R. Galdanova, devotion to the eagle among the Buryats was associated with the solar cult (Ibid.: 37). It should be mentioned that the images of the eagle and horse, which were also related to the solar cult, have similarities in the beliefs of the Buryats. The sounds made by the eagle and horse are conveyed in the Buryat language by the same word insagaalga 'neighing, squawking' (Buryaad-orod toli, 2010: Vol. 1, p. 447). These animals are united by a struggle with the same enemy - the snake, a chthonic creature, although in Buryat myths and tales, the role of the eagle in this confrontation is often played by the mythical bird Garudi. Judging by the shamanic folklore, the eagle can destroy other serpent-like beings, for example the worm (Shamanskiye poveriya..., 1890: 16). The eagle like the horse serves the light forces. Their pantheon included Khan Burged tengri 'King Eagle celestial dweller', personifying the daylight. Both animals served as guides from the Middle World to other worlds.

In the Buryat myths and fairy-tales, dalitan morin 'winged horse', which carries the cultural hero over long distances, is the bearer of the features of horse and bird. According to the views of the Buryats, the head of the western celestial dwellers, the deity of the light Khormusta, has the winged horse for riding around the celestial dome.

In ancient times, the population of the Cis-Baikal region identified the eagle with the sky. According to A.P. Okladnikov, the figure of the soaring eagle on the petroglyphs from the Trans-Baikal region embodies the image of a bearer of a luminous celestial power, a guarantee of fertility and happiness (Okladnikov, Zaporozhskaya, 1970: Pt. 2, p. 122-123).

The image of the eagle is the key image in Buryat shamanism. According to traditional views, the first shaman was the eagle who handed his gift to an earthly woman (Khangalov, 1959: Vol. 2, p. 130). It is no coincidence that the Buryats believed that a person who tasted the meat of an animal killed by an eagle becomes a shaman. Only men could eat such meat. Women were strictly forbidden not only to taste it, but even to approach the carcass of the animal, so as not to defile the deity who was believed to take the form of the eagle. According to folk beliefs, a shaman could turn into an eagle to go on a journey, for example to the other worlds, 
or to fight with another shaman. The shaman's outfit of the Buryats reflected a connection with this bird, as well as with the sacred sky and sun. For example, among the Cis-Baikal Buryats, the shaman had the orgoi headdress, which was made of eagle skin removed together with the wings (Ibid.: 183) (the Khakas shamans had similar headgear (Butanaev, 2006: 73)); the shamans among the Agin Buryats had a metal chest mirror toli, featuring a representation of an eagle symbolizing Khan Burged tengri (RME, No. 783-10). The Cis-Baikal Buryats considered Khan Khoto baabai a family patron, and made the required sacrifices. In the traditional views of the Siberian Turkic peoples, the image of the eagle was also associated with the cults of the Sky and Sun (Burnakov, 2010: 162).

Ideas about other daytime birds of prey among the Buryats were extremely limited and mainly concerned the hawk and kite. The traditional Buryat territories were a habitation for khara shekhetei elee 'black-eared kite' (Milvus migrans lineatus), bulzhamuurai kharsaga 'Eurasian sparrowhawk' (Accipiter nisus), and khurdeg, hoyrsho kharsaga, honosho kharsaga 'Northern goshawk' (Accipiter gentilis). The attitude of the Buryats towards kites was mostly negative. However, it was believed that in the summer these birds were protected by masterspirits, and at that time it was not allowed to hunt them; this prohibition did not apply to the rest of the year (Khangalov, 1960: Vol. 3, p. 37). Among the Buryats, the kite was perceived as an ominous bird. According to a popular belief, if a kite screeches... it portends rain and prolonged misfortune (Ibid.: 74). People believed that an evil spirit could take on the appearance of this bird (Gomboev, 1864: 58). According to traditional beliefs, some shamans could turn into this bird of prey for their travels (Shamanskiye poveriya..., 1890: 9). The kite was revered in the shamanistic invocations of the Cis-Baikal Buryats.

The Buryats admired the physical qualities of the hawk. This is confirmed by the following epithets: kharsaga solbon khukhy 'a cuckoo as agile and deft as a hawk', kharsaga boro morin 'a gray horse as fast as a hawk', kharsaga tahartai 'with hawkish eyes'. In fairy-tales, not only did heroes turn into hawks, but also their opposites (mangadkhaias), which could indicate ambivalence of this bird for the Buryats. Hawks played an important role in the ritual practices of the shaman. It was believed that some shamans could take the form of a hawk in a mystic battle with a hostile shaman (Zhamtsarano, s.a.).

The Buryat vocabulary contains ornithonyms related to tuun turlaag 'the Corvidae': tuun, alag tuun 'Alpine chough' (Pyrrhocorax graculus), ubsuu sagaan turlaag 'Daurian jackdaw' (Coloeus dauuricus), alag shaazgai 'common magpie' (Pica pica), itag shaazgai 'Eurasian jay' (Garrulus glandarius), ongolo 'spotted nutcracker' (Nucifraga caryocatactes), turlaag 'common raven'
(Corvus corax kamtschaticus), khara khiree 'carrion crow' (Corvus corone). Images of the raven, the magpie, and the jackdaw from the Corvidae family occur in the set of Buryat beliefs.

In traditional Buryat consciousness, the raven was one of the first creatures created by the "thousands of celestial gods" along with the swan (Zhamtsarano, 2001: 84). It was perceived as a sacred figure, determining the rhythms of nature, "Black raven has started to croak-the spring has come" (Uligery khori-buryat, 1988: 88). Raven was considered the son of Azhirai Bukhe, the mythical spiritmaster of the Lena River, who was one of the thirteen northern Noyans. Therefore, raven was regarded as a messenger of the black eastern celestial dwellers, who had his own patron spirit; killing ravens was prohibited (Khangalov, 1960: Vol. 3, p. 74). In the beliefs of the Buryats, this bird had a negative connotation, which resulted from its biological features, such as black plumage, habit of eating carrion, and sharp croaking. The belonging of the raven to the dark world was emphasized in mythology. For example, the epic "Altan Shagai mergen" has an expression: "Black raven screams, and yellow fox barks" (Skazaniya buryat..., 1890: 17). Fox was called the "dog of Erlen" and was a guide to the Lower World (Khangalov, 1960: Vol. 3, p. 69).

The beliefs concerning "eternal black water", endowing the raven with immortality (Potanin, 2005: 348 ), were associated with that bird. Such views are also known among other Turkic-Mongolian peoples (Burnakov, 2010: 158).

Raven was addressed to in shamanistic invocations. One of the elements of the vestments worn by Buryat shamans also testifies to the sacred role of this bird: the shaman's hat malgai worn underneath the iron crown is decorated with the zalaa 'tassel', to which a raven feather was attached (RME, No. 783-2).

According to the Buryats, the crow was a bad bird: it was described by the same set of morphological features as the raven. It was distinguished by a throaty cry which, as people believed, did not forebode anything good. It was considered a bad omen if a crow sat on the roof of the house and croaked loudly (Khangalov, 1960: Vol. 3, p. 74). However, its cry could also be taken as a good sign: "If it screams with another sound, it forebodes wealth" (Smolev, 1900: 28). The crow was credited with the abilities of a shapeshifter; in fairy-tales, the servants of mangadkhai turn into it. Among the Buryats, this bird was associated with such human vice as greed: khentei khun khiree mete 'the greedy man is like a crow'.

The Buryat beliefs about the Corvidae mentioned above correspond in detail to the beliefs of the Siberian Turkic peoples. For instance, both endow these birds with chthonic properties; the motif of things belonging to this bird appears in their symbolism, and shamanistic practice is connected with the raven. 
In the Buryat worldview, the image of other Corvidae (magpie and jackdaw) appears as ambivalent. The fairytales of the Buryats indicate that the golden-chested magpie contains the soul of mangadkhai. If a magpie builds a nest in the yard, it is a bad omen. The belief that this bird is a harbinger of misfortune was reflected in the legend on the migration of the Khorsites from the Western Trans-Baikal region to Mongolia: this tribe interpreted the appearance of the magpie as a harbinger of the arrival of "people with yellow hair and unusual collars", and left the land of their ancestors forever (Natsov, 1995: 10-11).

The magpie is credited with ability to predict events. Different groups of Buryats had different opinions on the subject. For example, the Cis-Baikal Buryats believed that "If a magpie chatters in someone's yard in the morning, this foreshadows misfortune. If a magpie screams in the evening, this is good" (Khangalov, 1960: Vol. 3, p. 73). The Selenga Mongols interpreted the magpie chattering in a different way: "If a magpie chatters at the yard before morning and evening, this foreshadows misfortune. If a magpie chatters during the daytime with its head to the yurt, this foreshadows well-being" (Smolev, 1900: 28). The Agin Buryats associated pleasant events with that bird: "If a magpie chatters nearby, a joyful meeting should be expected" (Zhamtsarano, 2001: 181). Similar ideas about the magpie as bearing the news have been recorded among the Khakas people (Burnakov, 2009: 431).

In the traditions of the Buryats, the magpie acted as the savior of the mother of the founder of the Narat clan, who happened to be in the taiga on the verge of death (Khangalov, 1960: Vol. 3, p. 378). In a similar role, the magpie is shown in the legend of the Tunka Buryats about the Zangyasan River (Dubrova, 1884: 30).

Traditionally, the features caused by its morphology were emphasized with irony in the image of the magpie. As an example, we should cite a riddle about the magpie: teeg-teeg yabadaltai, tekhe haaral gutaltai, alag bulag dakhatai, altan urga shereehetei 'walks with a skip, wears shagreen boots, a mottled coat, drags a gilded pole'. Buryat folklore focused on the bird's selfish behavior, for which all its offspring was punished.

The jackdaw was perceived negatively because of its black plumage and especially because of its habit of feeding on dead flesh, common with the crows. The jackdaw was endowed with ability to foretell bad weather (Khangalov, 1960: Vol. 3, p. 73). Jackdaws were considered useful in popular medicine. For healing from rabies, witch doctors used feathers of Alpine chough, with which the patient was fumigated; for medicinal purposes, the patient was also prescribed to listen to its cries (Potanin, 2005: 707).

The Buryat vocabulary contains ornithonyms for nightly birds of prey, such as eagle-owl, night owl, and horned owl: shara shubuun 'Eurasian eagle-owl' (Bubo bubo), bug, begserge, uuli, huukhirdeg 'long-eared owl' (Asio otus), tazhaa 'snow owl' (Bubo scandiacus), begserge, uuli, bukha shubuun 'boreal owl' (Aegolius funereus). Only the eagle-owl has a positive image among the representatives of the Strigidae family listed above. According to popular beliefs, this bird protected young children from ada anakhai 'evil spirits' (Khangalov, 1960: Vol. 3, p. 39-40). This is why an eagle-owl chick was brought to live in the families where babies had died. It was the so-called shaman-eagle-owl, which was chosen according to the following criteria: "It gazes without blinking, what other birds cannot do, and has two bundles of feathers like horns on its head" (Chistokhin, 1878: 232). This bird lived with the child and, as the relatives of the baby believed, guarded its life. People also believed that the eagle-owl was under the protection of "white", good celestial beings, and for this reason they dedicated sprinkling with milk to eagle-owls, similarly to eagles and swans (Potanin, 2005: 92). During the ritual of worshiping the ongons, it was customary among the CisBaikal Buryats to tie a feather of an eagle-owl to a bride's hat. At the end of the ritual, this feather was hidden in the dere head cushion (Zhamtsarano, 2001: 58), which had a sacred purpose. The feather of the eagle-owl in this case symbolized the protection of the young family by deities of light.

According to popular belief, this bird was as a messenger of protracted illness: "If at night an eagle-owl sits in the yard and screams, there will be a sick person for a long time" (Smolev, 1900: 28).

The image of the eagle-owl was included among the Buryat shaman's accessories: eagle-owl feathers were attached between the horns of the shaman's iron crown among the Agin Buryats (RME, No. 783-1).

If the eagle-owl was considered a messenger of the luminous powers of the Upper World, the owl (more precisely, the snowy owl), which was believed to live not only on earth, but also in a watery environment, belonged to the Lower (dark) World (Potanin, 2005: 184). Nevertheless, the owl was an object of devotion: the shamans addressed it in invocations. The Buryat language testifies to the negative attitude towards the owl. For example, one of the meanings of the owl's name is bug 'evil spirit'. G. Gomboev pointed out that since ancient times the Selenga Mongols considered the owl a sinister creature (1859: 250). It can be assumed that the image of this bird had an ambivalent connotation. For instance, in the tales about the son of the sky, a celestial being who conceived him appeared to an earthly woman in the form of an owl (Potanin, 2005: 674).

The motif of the soul-bird in Buryat folklore can be illustrated by the quail (bydke 'common quail' (Coturnix coturnix)). In the tale "Kharasgai Mergen", the souls of the seven grandchildren of an evil old woman were enclosed in seven quails (Buryatskiye volshebniye skazki, 1993: 51-59). In the text "Brave Zhebzhenei", the soul 
of the representative of the dark forces mangadkhai was hidden in thirteen quails (Ibid.: 88-90). All this indicates a negative connotation of the image of the quail.

The Buryats associated the beginning of the warm season with the cuckoo (khykhy, khybkhuu 'common cuckoo' (Cuculus canorus)): "The king cuckoo is cuckooing, the summer has come" (Uligery khori-buryat, 1988: 88). In the popular calendar, this was reflected in the name of the last month of the spring — khukhyn duuna hapa 'month of cuckooing, May' (Zhamtsarano, 2001: 80). In the tradition of the Turkic peoples of Southern Siberia, the cuckoo was also considered a herald of the approaching summer (Burnakov, 2008: 305).

The Buryats negatively perceived this bird. According to legend, in its former life it was a dissolute woman, and for that she was punished by God (Khangalov, 1960: Vol. 3, p. 28). People came up with the figurative name for the cuckoo-khan khukhy "royal" cuckoo (because it does not feed the chick on her own)' (Burayad-orod toli..., 2010: Vol. 2, p. 393). It was considered a harbinger of hungry times: "If a cuckoo cuckoos very much, it will be a bad year" (Potanin, 2005: 133). The Cis-Baikal Buryats paid attention to the time of day when the bird cuckooed: "If a cuckoo cuckoos at night, it will be a lean year, but in a good year it does not cuckoo at all" (Zhamtsarano, 2001: 85).

Buboloshen 'hoopoe' (Upupa epops) was among the birds that were negatively perceived by the Buryats. The nesting of this bird under the roof of the house (Potanin, 2005: 133) or under the floor was considered a bad omen for the family. It was believed that this could bring misfortune to the household (Zhamtsarano, 2001: 250). Flights of hoopoe near human buildings also belonged to the category of bad omens (Khangalov, 1960: 73). In the beliefs of the Buryats, this bird was associated with the end of summer and onset of autumn cold. According to the popular calendar, August was called the month of hoopoe.

\section{Conclusions}

The study of the traditional ornithomorphic beliefs of the Buryats has made it possible to establish which birds were revered. Some of them, such as the swan, the goose, the duck, the dove, and the eagle, were considered totemic ancestors and had local cults. In popular culture, the swan, the crane, the swallow, the dove, the eagle, and the eagleowl had positive connotations; the kite, the raven, the crow, the quail, the cuckoo, and the hoopoe bore negative connotation, while the duck, the hawk, the magpie, and the jackdaw carried ambivalent connotation. The Buryats associated the duck and the crow with the cosmogonic idea. One popular subject was the transformation of a person or animal into a bird-a swan, a goose, etc. The images of a number of birds are reflected in the Buryat shamanic paraphernalia, and have been incorporated into mythological practices. In popular belief, birds (ravens, cuckoos, hoopoes) symbolized the rhythms of nature. The Buryats associated beliefs about the bird/soul with the magpie and the quail, and they considered such birds as the magpie, the owl, the hoopoe, the crow, and others capable of predicting future events.

The traditional beliefs of the Buryats concerning a number of birds are similar to the beliefs held by other peoples of Southern Siberia and Central Asia, which indicates the presence of universal and local subjects in the Buryat mythology, and also ethnic and cultural contacts in the past.

\section{Acknowledgments}

This study was performed under the R\&D Project "Symbol and Sign in the Culture of the Peoples of Siberia in the 17th to 21st Centuries: Actualization and Strategies of Maintenance".

References

Baikal: Priroda i lyudi: Entsiklopedicheskiy

spravochnik. 2009

Ulan-Ude: EKOS, izd. BNC SO RAN.

Batorov P.P. 1927

Kult orla u severo-baikalskikh buryat. Buryatiyevedeniye, No. 4: 79-81.

Batorov P.P., Khoroshikh P.P. 1926

Materialy po narodnomu skotolecheniyu irkutskikh buryat. Buryatovedcheskiy sbornik, iss. 2: 50-59.

Burnakov V.A. 2008

Obraz kukushki v mifo-poeticheskoy i ritualnoy traditsii khakasov. In Problemy arkheologii, etnografii, antropologii Sibiri i sopredelnykh territoriy, vol. XIV. Novosibirsk: Izd. IAET SO RAN, pp. 305-309.

Burnakov V.A. 2009

Obraz soroki v mifologicheskikh vozzreniyakh khakasov. In Problemy arkheologii, etnografii, antropologii Sibiri $i$ sopredelnykh territoriy, vol. XV. Novosibirsk: Izd. IAET SO RAN, pp. 429-433.

Burnakov V.A. 2010

$\mathrm{K}$ voprosu o kulte orla u khakasov. In Mirovozzreniye naseleniya Yuzhnoy Sibiri i Tsentralnoy Azii v istoricheskoy retrospektive, iss. IV. Barnaul: Azbuka, pp. 153-164.

Buryaad-orod toli. Buryatsko-russkiy slovar. 2010

K.M. Cheremisov, L.D. Shagdarov (comp.): In 2 vols. UlanUde: [Respublikanskaya tip.].

Buryatskiye narodniye skazki. O zhivotnykh.

Bytoviye. 2000

E.V. Barannikova, S.S. Bardakhanova, V.S. Gungarov, and B-K.B. Tsybikova (comp.). Novosibirsk: Nauka. (Pamyatniki folklora narodov Sibiri i Dalnego Vostoka; vol. 20).

Buryatskiye volshebniye skazki. 1993

E.V. Barannikova, S.S. Bardakhanova, V.S. Gungarov. Novosibirsk: Nauka. (Pamyatniki folklora narodov Sibiri i Dalnego Vostoka; vol. 5). 
Buryaty. 2004

Moscow: Nauka.

Butanaev V.Y. 2006

Traditsionniy shamanizm Khongoraya. Abakan: Izd. Khakas. Gos. Univ. im. N.F. Katanova.

Chistokhin Y. 1878

Obychai buryat pri rozhdenii i pervonachalnom vospitanii detey. Missioner, No. 29: 231-232.

Dubrova Y.P. 1884

Ekspeditsiya k beregam r. Selengi. Izvestiya VSOIRGO, vol. XV (1/2): 1-92.

Galdanova G.R. 1987

Dolamaistskiye verovaniya buryat. Novosibirsk: Nauka.

Gomboev G. 1859

O drevnikh mongolskikh obychayakh i suyeveriyakh, opisannykh u Plano Karpini. Trudy Vostochnogo otdeleniya Imperatorskogo arkheologicheskogo obshchestva, pt. 4: 236-256.

Gomboev G. 1864

Glubokomudraya Chuga, po kosti lopatki, izlozhennaya Mandzhushiriyem. Trudy Vostochnogo otdeleniya Imperatorskogo arkheologicheskogo obshchestva, pt. 8: 1-61.

Gura A.V. 1997

Simvolika zhivotnykh v slavyanskoy narodnoi traditsii. Moscow: Indrik.

Khangalov M.N. 1958, 1959, 1960

Sobraniye sochineniy: In 3 vols. Ulan-Ude: Buryat. kn. izd. Manzhigeev I.M. 1960

Yangutskiy buryatskiy rod (opyt istoriko-etnograficheskogo issledovaniya). Ulan-Ude: Buryat. kn. izd.

Mitroshkina A.G. 1987

Buryatskaya antroponimiya. Novosibirsk: Nauka.

Natsov G.D. 1995

Materialy po istorii i kulture buryat, pt. 1. Ulan-Ude: Izd. BNC SO RAN.

Okladnikov A.P., Zaporozhskaya V.A. 1970

Petroglify Zabaikalya, pt. 2. Leningrad: Nauka.
Podgorbunsky I.A. 1915

Skazki i pesni buryat. Izvestiya VSOIRGO, vol. XLIV: 90-107.

Potanin G.N. 2005

Ocherki Severo-Zapadnoy Mongolii. [2nd edition]. GornoAltaysk: Ak-Chechek.

Shamanskiye poveriya inorodtsev Vostochnoy

Sibiri. 1890

Irkutsk: [Tip. K.I. Vitkovskogo]. (Zapiski VSOIRGO; vol. 2, iss. 2).

Skazaniya buryat, zapisanniye raznymi

sobiratelyami. 1890

Zapiski VSOIRGO, vol. 1 (2). Irkutsk.

Smolev Y.S. 1900

Tri tabangutskikh roda selenginskikh buryat: Etnograficheskiy ocherk. Moscow: [Tov-vo tip. A.I. Mamontova].

T.S. (Savenkov Timofei). 1925

Baikal. Sibir, No. 4: 16-17.

Uligery khori-buryat. 1988

Ulan-Ude: Buryat. kn. izd.

Vinokurova I.Y. 2007

Zhivotniye v traditsionnom mirovozzrenii vepsov (opyt rekonstruktsii). D.Sc. (History) Dissertation. St. Petersburg.

Zhamtsarano T.Z. 2001

Puteviye dnevniki 1903-1907 gg. Ulan-Ude: Izd. BNC SO RAN.

Zhamtsarano T.Z. (s.a.)

Opisaniye shamanstva u aginskikh khori-buryat i primechaniye k kollektsii No. 783 po shamanstvu. CVRK IMBT SO RAN. F. 6, Inv. 1, D. 28.

Zinner E.P. 1968

Sibir v izvestiyakh zapadnoyevropeiskikh puteshestvennikov i uchenykh XVIII veka. Irkutsk: Vost.-Sib. kn. izd.

Received May 13, 2019.

Received in revised form July 17, 2019. 